\title{
Feasibility Study to Install Wind Farm in Bab Al-Hawa, Irbid, Northwest of Jordan
}

\author{
Mohammad Al-Smairan ${ }^{1}$, Omar Al-Nhoud ${ }^{2}$ \\ ${ }^{1}$ Renewable Energy Engineering Department, Faculty of Engineering, Al al-Bayt University, Mafraq, Jordan \\ ${ }^{2}$ Civil Engineering Department, Faculty of Engineering, Al al-Bayt University, Mafraq, Jordan \\ Email: *wesam93@yahoo.com
}

How to cite this paper: Al-Smairan, M and Al-Nhoud, O. (2019) Feasibility Study to Install Wind Farm in Bab Al-Hawa, Irbid, Northwest of Jordan. Modern Mechanical Engineering, 9, 30-48. https://doi.org/10.4236/mme.2019.91004

Received: January 21, 2019

Accepted: February 24, 2019

Published: February 27, 2019

Copyright $\odot 2019$ by author(s) and Scientific Research Publishing Inc. This work is licensed under the Creative Commons Attribution International License (CC BY 4.0).

http://creativecommons.org/licenses/by/4.0/

\begin{abstract}
The utilization of wind energy for power generation purposes is becoming increasingly attractive and gaining a great share in the electrical power production market worldwide. This research was considered a feasibility study of wind energy farm in Bab Al-Hawa, Irbid. The average wind speed in the site is $(6.5 \mathrm{~m} / \mathrm{s})$. Data have been collected, which includes the average monthly wind speed for 10 years, but by HOMER software to create the hourly wind speed of a representative year is created in order to build Weibull distribution and to calculate the energy generated output of the project. This project contains the construction of 33 wind turbines in $3.11 \mathrm{~km}$ square. Each turbine has a capacity of $900 \mathrm{~kW}$ rated power and the total rated capacity is $29.7 \mathrm{MW}$. The capacity factor was found equal to $37.1 \%$ which means the amount of utilization of the turbine capacity. The results show that the turbines work $87,286 \mathrm{~h} / \mathrm{yr}$, and the total energy generated is $96.548559 \mathrm{GWh} / \mathrm{yr}$. from the 33 wind turbines installed. The initial cost of this project is equal to 80.5243 $\mathrm{M} \$$ and the Payback period is 7 years. We have taken into account the environmental impact such as $\mathrm{CO}_{2}$ emissions into consideration. $\mathrm{CO}_{2}$ reductions by using wind energy instead of coal-fired plant are equal to 67124.4 tons, and the $\mathrm{CO}_{2}$ emissions reduction using wind power instead of fuel oil power plant is 5343.4 tons. This research shows that wind farm at Bab Al-Hawa with a capacity of $29.7 \mathrm{MW}, 33$ wind turbines, $900 \mathrm{~kW}$ each has been feasible with a cost of energy 4 cents/kWh.
\end{abstract}

\section{Keywords}

Wind Farm, Bab Al-Hawa, HOMER Software, Energy, Capacity Factor

\section{Introduction}

Energy is considered a prime agent in the generation of wealth and a significant 
factor in economic and social development. Limited fossil fuel resources and environmental problems associated with them have emphasized the need for new sustainable energy supply options that use renewable energies. Among available technologies for energy production from wind energy could give a significant contribution to develop a more sustainable energy system [1].

Historically, economic development has been strongly correlated with increasing energy use and growth of greenhouse gas emissions. Renewable energy can help decouple that correlation, contributing to sustainable development. In addition, renewable energy offers the opportunity to improve access to modern energy services for the poorest members of society.

The same principle is behind the generation of electricity through the turbines of wind farms. At sea or on land, these giant spinning windmills capture the power of the air around it. Some countries have made a national industry of generating its power from wind. In 2015, Denmark broke its own world record by producing over $40 \%$ of its national power from wind energy. Wind power is far more popular in Europe than in North America, with nearly having of the global capacity produced across various European countries. Many of these are at sea where most of the wind power is produced.

Wind energy, as one of our most abundant resources, is the fastest growing renewable energy technology worldwide, but wind energy generation is not constant and varies from season to season and even day to day, even though periods of low and high wind can be easily predicted. This means that warm, dry summers with very little wind mean that other sources of energy generation will be needed to make up any potential shortfall [1].

Energy from wind generation is also geographically limited, the best places are at sea and on vast plains. There are areas where they are completely unsuitable such as in mountain valleys and in urban sites where natural and artificial structures will shield any turbines from wind capture. On top of mountains may be a good place, but the wind must be strong enough to warrant placement. Poor placement could be a hindrance and not an advantage to power generation [2] [3] [4].

Jordan imported $97 \%$ of its energy needs from outside countries, in addition Jordan is a poor country with fossil-fuel resources, but has an abundant solar energy resource and a good wind energy source in some parts of the country. Therefore, the Jordanian government published the 2007-2020 Updated Master Strategy of the Energy Sector that builds upon the 2004 National Master Strategy during which various challenges were faced that impeded the implementation of several projects. One of the main objectives of this strategy is ensuring renewable energy contributes to about $10 \%$ of the total energy mix by 2020 , as shown in Figure $1[5]$.

Jordan possesses high potential of wind energy resources where the annual average wind speed exceeds $7 \mathrm{~m} / \mathrm{s}$ (at $10 \mathrm{~m}$ height) in some areas of the country. The Wind Atlas indicated out two windy regions in the northern and southern parts of Jordan [6]. 


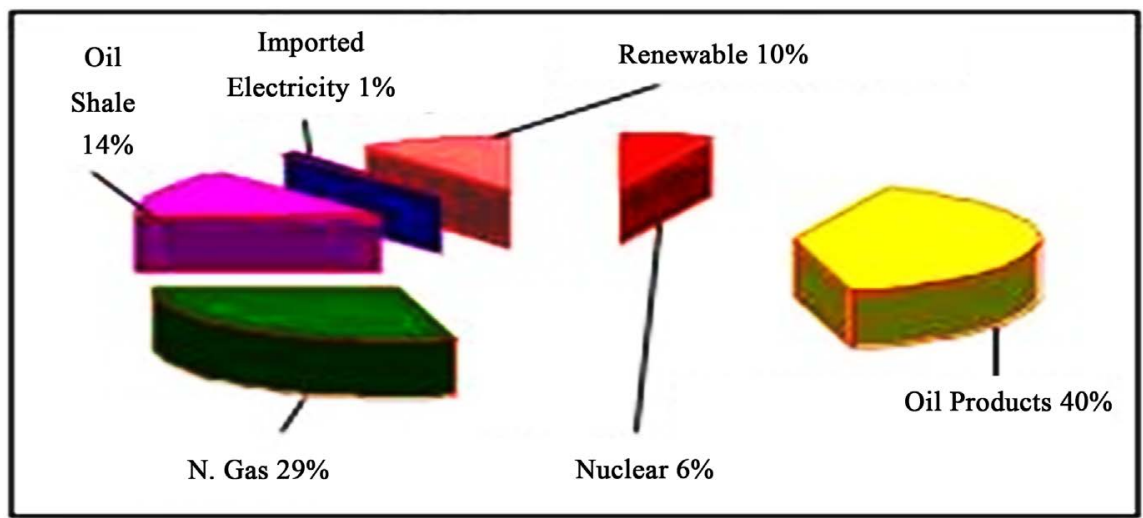

Domestic Resources 39\%, Imported 61\%

2020

Figure 1. Jordan energy strategy for 2020.

The innovation of this works comes from that this research was the first one carried out in Jordan. All wind farms installed in Jordan specially in south region of Jordan depend on Jordan wind atlas which was built during the last century. This research depends on new data and recommended software. There is no someone has done similar work in the region.

\section{Study Area}

The research will be carried out at a site called Bab Al-Hawa, Northwest of Jordan, it's an open hill and is approximately $13 \mathrm{Km}$ south-west of Irbid city, the major city in the Northwest of the country. The site is a treeless and that is well exposed to the prevailing westerly wind and for other wind in winter and summer seasons, average wind speed in location is about $(6.5 \mathrm{~m} / \mathrm{s})$.

The site is near to other wind projects such as, Hoffa Al-Mazar and Al-Ibrahemieh project. There are many criteria take into account and paid attention for this project such as the site topography, wind speed, and small population.

\section{Tools and Methodology}

\subsection{Introduction}

Site selection for large wind turbine requires consideration of a comprehensive set of factors and balancing of multiple objectives in determining the suitability of a particular area for a defined land use. The selection of suitable project areas involves a complex array of critical factors drawing from physical, demographical, economic, policies, and environmental disciplines. The current spatial decision making could benefit from more systematic methods for handling multi-criteria problems while considering the physical suitability conditions. Selection criteria must also satisfy the optimistic criteria. 


\subsection{Site Selection Tools}

Geographic information systems (GIS) has been used in solving site selection problems, which is a computer system for capturing, storing, checking, and displaying data related to positions on earth's surface. By relating seemingly unrelated data, GIS can help individuals and organizations better understand spatial patterns and relationship [7].

\subsection{Data Collection}

In this project data are very important for selecting the type and numbers of turbine, this data includes: average daily wind speed for many years in the site. We have to use two software programming, Homer software to getting the average daily wind speed since the available data is only average monthly wind speed, and Google sketch up to modeling and simulation the turbines in the site.

\subsubsection{HOMER Software}

Homer is a free software application developed by the National Renewable Energy Laboratory in the United States. This software application is used to design and evaluate technically and financially the options for off-grid and on-grid power systems for remote, stand-alone and distributed generation applications. It allows you to consider a large number of technology options to account for energy resource availability and other variables [7].

\subsubsection{Sketch up Software}

Formerly Google Sketch up, is a 3D modeling computer program for a wide range of drawing applications such as architectural, interior design, landscape architecture, civil and mechanical engineering, film and video game design and can used it for drawing wind turbine [8].

The Weibull distribution is one of the most widely used lifetime distributions in reliability engineering. It is a versatile distribution that can take on the characteristics of other types of distributions, based on the value of the shape parameter $\mathrm{k}$ and scale parameter $\mathrm{c}$ [9]. Finally, calculate the energy output from the turbines, economic and environmental aspect then evaluate the project.

\section{Data and Calculations}

\subsection{Site Selection}

In designing wind projects and wind turbine for generating electricity many parameters must take into account to get the best design of any project. Bab Al-Hawa/Irbid area has been chosen. Many factors were considered to choose this area, such as its height above the earth surface (this area is located in open hill) which make it have a plenty of wind all over the year, far from residential communities, close to water services, and it does not contain any noticeable obstacles such as buildings, large trees, and huge mountains.

GPS and GIS programs have been used to choose the best piece of land to install the wind farm. This specific area has the best height, far from streets and 
cars traffic and it's the least area contain trees which contributes less cutting of trees when the project applied, Figure 2, (Table 1).

\subsection{Data Collection}

For any energy generation design project collect an accurate data is the most important thing that is required, because this leads to an accurate calculation and results which make the design meet the required conditions. The most important data that is necessary for wind farm design is the daily wind speed for many years (almost 10 years).

To obtain this data, we headed for accredited and accurate government agencies, such as Ministry of Energy, Energy and Minerals Regulatory, Meteorological Department, Royal Scientific Society, and Irbid District Electricity Company (IDECO).

The average daily wind speed is not available for the selected site, the only available was the average monthly wind speed for 10 years. HOMER software was used to create the hourly wind speed of a representative year, Appendix 1 shows the average daily wind speed of the site for year 2012 .

\subsection{Wind Statistics and Weibull Distribution}

\section{Weibull Distribution}

It is a matter of common observation that the wind is not steady and in order to calculate the mean power delivered by a wind turbine from its power curve, it is

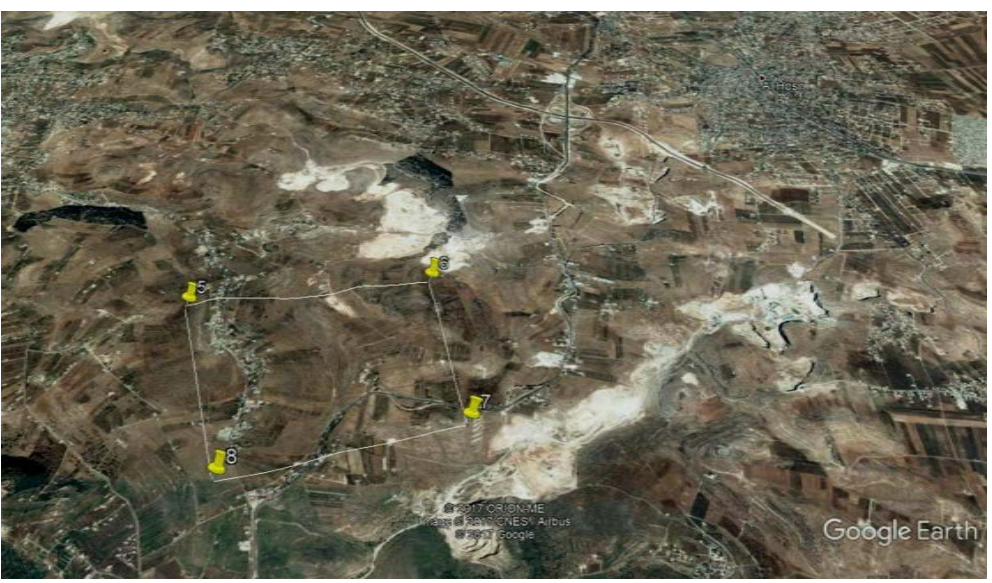

Figure 2. The area that chosen for install wind turbines, with pinned to determine the location from Google Earth.

Table 1. The specific location of chosen area.

\begin{tabular}{ccc}
\hline Pinned point & Latitude & Longitude \\
\hline 5 & $32^{\circ} 27^{\prime} 3.44 " \mathrm{~N}$ & $35^{\circ} 49^{\prime} 31.57^{\prime \prime} \mathrm{E}$ \\
6 & $32^{\circ} 27^{\prime} 14.22^{\prime \prime} \mathrm{N}$ & $35^{\circ} 50^{\prime} 44.25 " \mathrm{E}$ \\
7 & $32^{\circ} 26^{\prime} 25.65^{\prime \prime} \mathrm{N}$ & $35^{\circ} 50^{\prime} 57.83^{\prime \prime} \mathrm{E}$ \\
8 & $32^{\circ} 26^{\prime} 8.57^{\prime \prime} \mathrm{N}$ & $35^{\circ} 49^{\prime} 55.93^{\prime \prime} \mathrm{E}$ \\
\hline
\end{tabular}


necessary to know the probability density distribution function of the wind speed.

The basic measure of the unsteadiness of the wind is the standard deviation (or root mean square) of the speed variations. In order to calculate the mean power from a wind turbine over a range of mean wind speeds, a generalized expression is needed for the probability density distribution. An expression which gives a good fit to wind data is known as the Weibull distribution.

The two-parameter Weibull distribution is often used to characterize wind regimes has been found to provide a good fit with measured wind data. The probability density function is given by the following equation [10].

$$
f(v)=\frac{k}{c}\left(\frac{v}{c}\right)^{k-1} \cdot \exp \left[-\left(\frac{v}{c}\right)^{k}\right]
$$

where: $v=$ the wind speed $[\mathrm{m} / \mathrm{s}$ ],$k=$ the Weibull shape factor [unit less] and $c=$ the Weibull scale parameter $[\mathrm{m} / \mathrm{s}]$.

After using Homer to generate daily wind speed, Windoghrapher software was used to draw the Weibull distribution, the results are shown in Table 2 and Table 3.

\section{Scale parameter}

Appendix 2 shows the frequency and occurrence for each wind speed in the area. As we can see the most frequent wind speed is $6 \mathrm{~m} / \mathrm{s}$ and the least frequent are the speeds below $3 \mathrm{~m} / \mathrm{s}$ and above $10 \mathrm{~m} / \mathrm{s}$.

Figure 3 shows the probability distribution for wind speed during 2012.

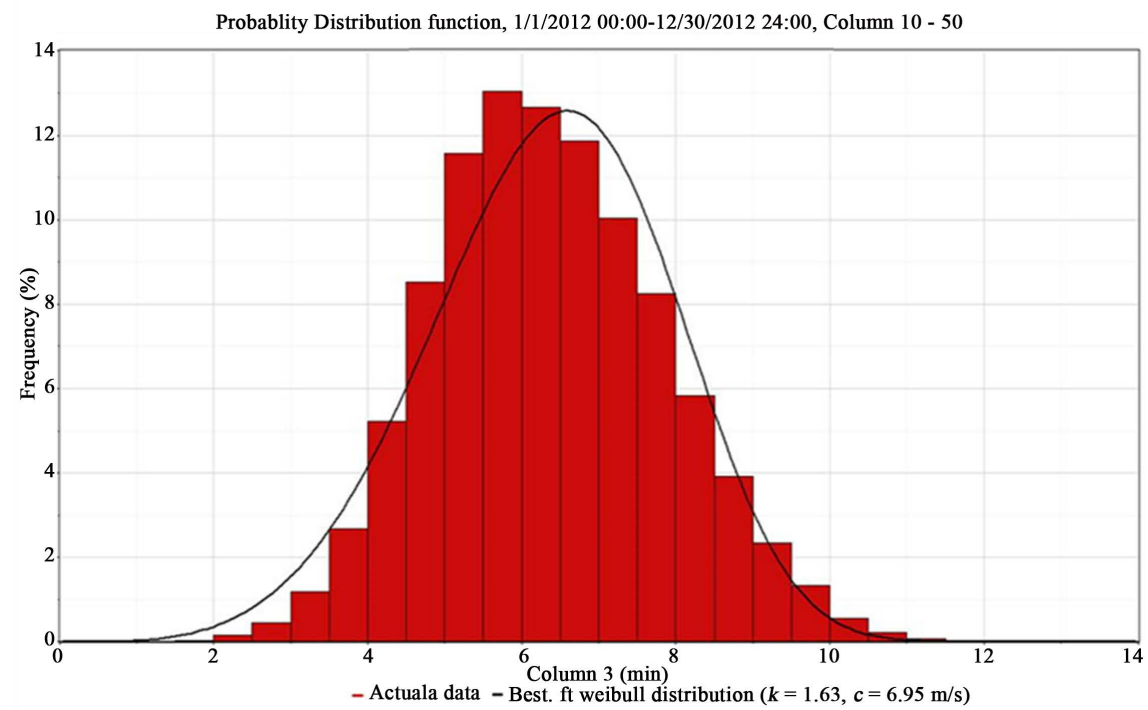

Figure 3. Weibull distribution from Windoghrapher, Bab Al-Hawa, Jordan 2012.

Table 2. Monthly shape parameter k from Windoghrapher Software.

\begin{tabular}{cccccccccccccc}
\hline Month & $\mathbf{1}$ & $\mathbf{2}$ & $\mathbf{3}$ & $\mathbf{4}$ & $\mathbf{5}$ & $\mathbf{6}$ & $\mathbf{7}$ & $\mathbf{8}$ & $\mathbf{9}$ & $\mathbf{1 0}$ & $\mathbf{1 1}$ & $\mathbf{1 2}$ & Yearly \\
\hline $\begin{array}{c}\text { Shape } \\
\text { parameter, } \mathbf{k}\end{array}$ & 4.9 & 4.8 & 4.6 & 4.5 & 4.7 & 4.7 & 5.0 & 4.4 & 4.2 & 4.5 & 4.2 & 4.2 & 4.6 \\
\hline
\end{tabular}


Table 3. Monthly scale parameter c from Windoghrapher Software.

\begin{tabular}{cccccccccccccc}
\hline Month & $\mathbf{1}$ & $\mathbf{2}$ & $\mathbf{3}$ & $\mathbf{4}$ & $\mathbf{5}$ & $\mathbf{6}$ & $\mathbf{7}$ & $\mathbf{8}$ & $\mathbf{9}$ & $\mathbf{1 0}$ & $\mathbf{1 1}$ & $\mathbf{1 2}$ & Yearly \\
\hline $\begin{array}{c}\text { Scale } \\
\text { parameter, c }\end{array}$ & 8.19 & 8.80 & 7.80 & 5.95 & 6.77 & 6.44 & 6.93 & 7.22 & 5.50 & 5.14 & 5.64 & 6.99 & 6.78 \\
\hline
\end{tabular}

\subsection{Wind Turbine Selection and Sitting}

\subsubsection{Wind Turbine Selection}

When we choose a wind turbine, the first thing we need to know are its cut in and rated wind speed and if it's suitable to the wind speed in the site. Also the area of the site controls the choice of the turbine because we have to make sure that the rotor diameter is suitable.

In our case many turbines were studied and we choose a EWT DW61-900 kW wind turbine. EWT's DIRECTWIND $900 \mathrm{~kW}$ turbine is a pitch controlled variable speed wind turbine that combines continuous market driven innovation with highly advanced direct drive technology. EWT $900 \mathrm{KW}$ turbine has more than one hub height and diameter, but we choose a 61 diameter and $75 \mathrm{~m}$ hub height, Figure 4.

Specifications of EWT's DW61-900 kW:

Rotor diameter: $61 \mathrm{~m}$

Rotor speed variable: 12 - $24 \mathrm{rpm}$

Hub heights: 46 and $75 \mathrm{~m}$

Rated wind speed: $11.5 \mathrm{~m} / \mathrm{s}$

Survival wind speed: $52.5 \mathrm{~m} / \mathrm{s}$
IEC wind class: IIIA

Nominal power output: $900 \mathrm{~kW}$

Cut-in wind speed: $2.5 \mathrm{~m} / \mathrm{s}$

Cut-out wind speed: $25 \mathrm{~m} / \mathrm{s}, 10 \mathrm{~min}$. avg Power output control: Pitch controlled

Power converter: IGBT-controlled

Cost of one turbine: $\$ 2.1127^{\star} 10^{\wedge} 6$.

The power curve of a wind turbine is a graph that indicates how large the electrical power output will be for the turbine at different wind speeds and also shows the cut in and rated wind speed. Figure 5 shows a power curve for a typical EWT DW61-900 KW turbine.

\subsubsection{Power Output Calculations}

Homer software has been used to simulate the collected data with the turbine specifications to calculate the energy and power output as shown in Table 4.

\subsubsection{Wind Turbine Sitting}

Micro-sitting/positioning of wind turbines in a given site refers to the process of optimizing total energy production of an entire wind park and at the same time take into account a number of environmental, economic, societal, technological etc. constraints by suitable placement of individual wind turbines. In most cases, however, current approaches concentrate on optimizing particular criteria that are usually related to technical and economic issues. Turbines sitting depend on the direction of the wind. In the direction of prevailing wind, we space between the turbines 7 times of diameter and perpendicular to wind direction 4 times of diameter [11]. 


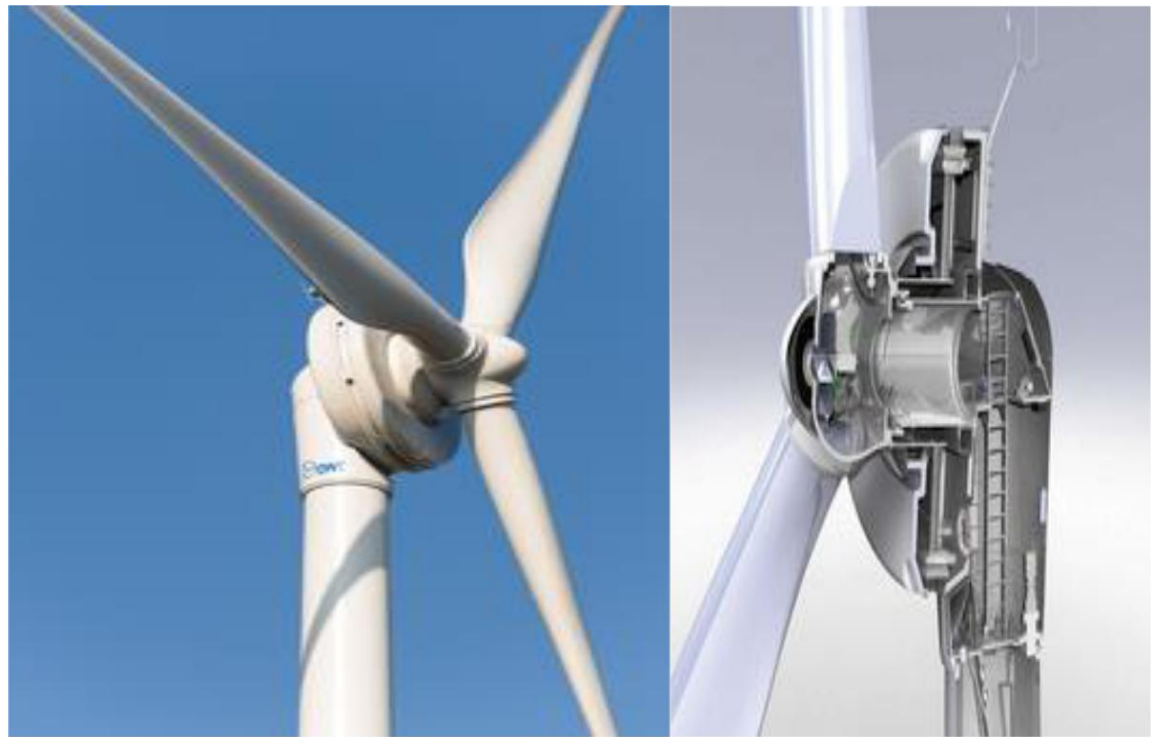

Figure 4. EWT DW61, [900 kW].

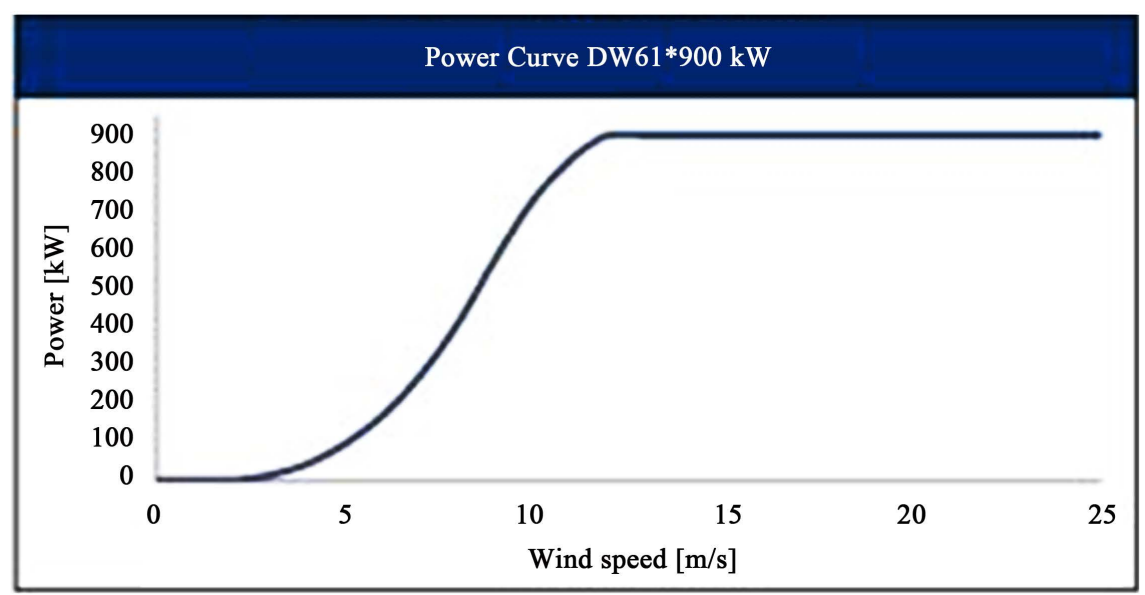

Figure 5. Power curve DW61-900 kW wind turbine.

Table 4. EWT DW61-900 KW energy and power output from HOMER.

\begin{tabular}{ccccc}
\hline $\mathrm{P}_{\max }(\mathrm{kW})$ & $\mathrm{P}_{\min }(\mathrm{kW})$ & $\mathrm{P}_{\text {mean }}(\mathrm{kW})$ & Energy output $(\mathrm{kWh})$ & Capacity factor (\%) \\
\hline 825 & 0 & 344 & $2,925,714$ & 37.1 \\
\hline
\end{tabular}

The length of the area chosen is $1.84 \mathrm{~km}$ on the direction of prevailing wind and its length is $1.69 \mathrm{~km}$ perpendicular to wind direction.

Space with wind $=7 \times 61=424 \mathrm{~m}$;

Space perpendicular $=4 \times 61=244 \mathrm{~m}$.

Figure 6 shows the number of turbines and its distribution on the site.

We found that the area fit to 33 wind turbine and the total rated capacity equal 29.7 MW.

\subsection{HOMER Simulation and Energy Generated}

HOMOER Pro was used to simulate the data and to find levelized cost, energy 


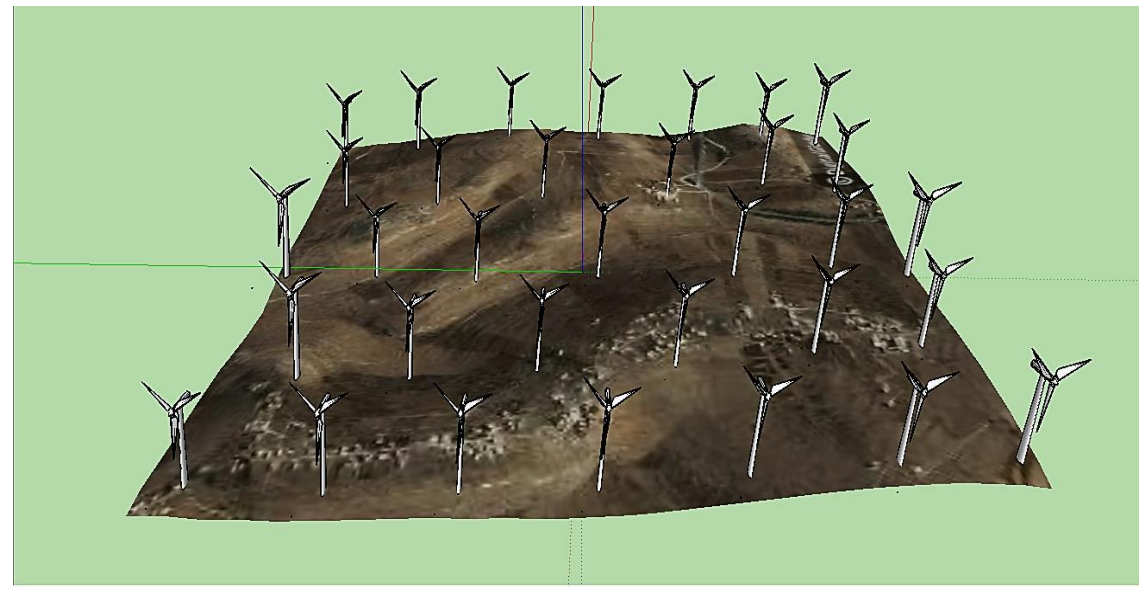

Figure 6. Turbine distribution in Bab Al-Hawa wind farm, Jordan form Google Sketch up Software.

generated through the year and net present cost analysis. Also, HOMER Pro used to connect the project with the grid and to determine the selling price for kWh.

\subsubsection{Wind Turbine Power Output}

As we can see from Figure 7 the levelized cost is $0.0559 \$ / \mathrm{kWh}$ which agree completely with the global levelized cost. The turbines worked $87,286 \mathrm{~h} / \mathrm{yr}$, and the total energy generated is $96.548559 \mathrm{GWh} / \mathrm{yr}$ from the 33 wind turbine installed.

Figure 8 shows the daily power output profile. January has the maximum power output, while, October has the least power output which means that it has the least wind speed, and the months (February-August) have a medium power output.

\subsubsection{Grid Connecting}

Wind farm have been connecting project to the grid, then, the sellback price for $\mathrm{kWh}$ of energy and the power energy price $\$ / \mathrm{kWh}$ have been determined as shown in Table 5.

Figure 9 shows the monthly energy produced and sold to the grid and the energy charge the grid pay for it. Annually energy charge that grid pay for the energy generated is $11.489278 \$$.

Energy charge $\$=$ energy generated $\times$ sellback price $\$ / \mathrm{kWh}$.

This number equals the saving during one year.

\subsection{Cost Analysis}

\subsubsection{Introduction}

Cost can be measured in a number of different ways, and each way of accounting for the cost of power generation brings its own insights. The costs that can be examined include equipment costs (e.g. wind turbines, etc.), financing costs, total installed cost, fixed and variable operating and maintenance costs $(\mathrm{O} \& \mathrm{M})$, fuel costs, and the levelized cost of energy (LCOE). 


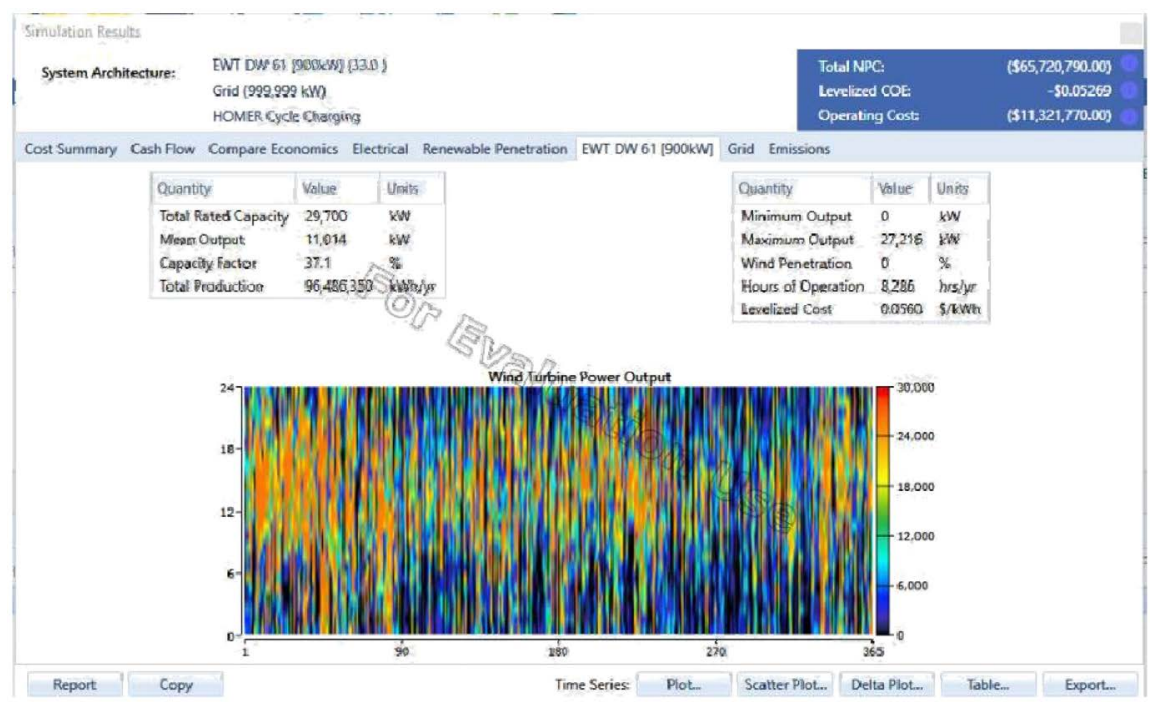

Figure 7. Wind turbine output results from HOMER Pro.

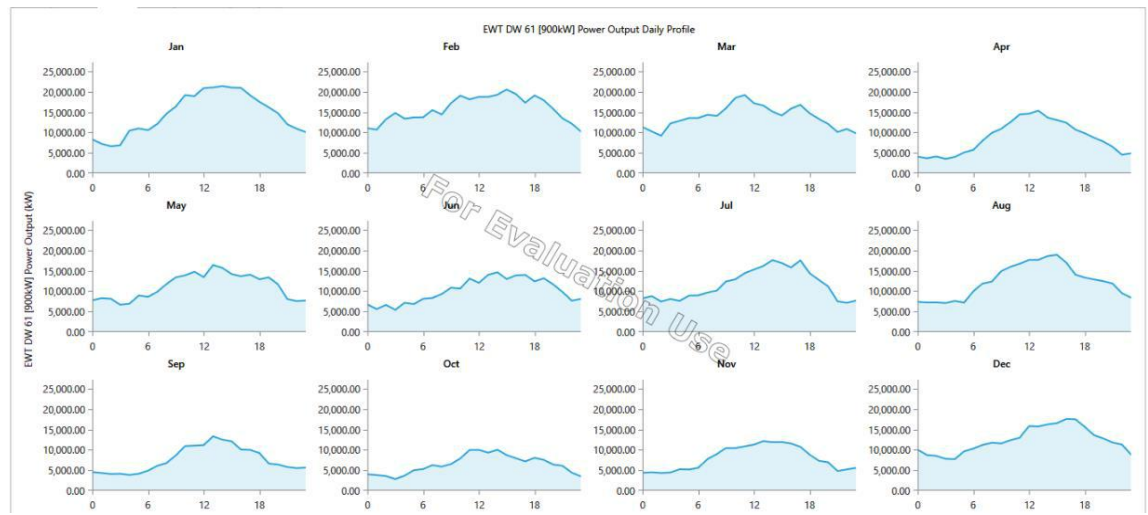

Figure 8. EWT DW61 $[900 \mathrm{~kW}]$ daily power output profile.

\begin{tabular}{|c|c|c|c|c|c|c|}
\hline Month & $\begin{array}{l}\text { Energy } \\
\text { Purchased } \\
\text { (kWh) }\end{array}$ & $\begin{array}{l}\text { Energy } \\
\text { Sold (kWh) }\end{array}$ & $\begin{array}{l}\text { Net Energy } \\
\text { Purchased } \\
\text { (kWh) }\end{array}$ & $\begin{array}{l}\text { Peak } \\
\text { Demand } \\
(\mathrm{kW})\end{array}$ & Energy Charge (\$) & $\begin{array}{l}\text { Demand } \\
\text { Charge (\$) }\end{array}$ \\
\hline May & 0 & $8,307,392$ & $-8,307,392$ & 0 & $(\$ 988,579.62)$ & so \\
\hline June & 0 & $7,298,907$ & $-7,298,907$ & 0 & (\$868,569.94) & so \\
\hline July & 0 & $8,610,501$ & $-8,610,501$ & 0 & (\$1,024,649.65) & so \\
\hline August & 0 & $9,239,375$ & $-9,239,375$ & 0 & (\$1,099,485.57) & so \\
\hline September & 0 & $5,458,423$ & 05.458 .423 & 0 & $(\$ 649,552.32)$ & so \\
\hline October & 0 & $4,771,064$ & $-4,771,064$ & 0 & $(\$ 567,756.67)$ & so \\
\hline November & 0 & $5,710,637$ & $-5,710,637$ & & $(\$ 679,565.77)$ & $\$ 0$ \\
\hline December & 0 & $9,179,187$ & $-9,179,187$ & 0 & $(\$ 1,092,323.31)$ & so \\
\hline Annual & 0 & $96,486,350$ & $-96,486,35$ & 0 & $(\$ 11,481,875.61)$ & so \\
\hline
\end{tabular}

Figure 9. Energy sold to the grid and energy charge in 2012.

Table 5. Prices for kWh for wind energy, from NEBCO.

Price of power energy $\$ / \mathrm{kWh}$
Grid Sellback price $\$ / \mathrm{kWh}$

0.119 
The analysis of costs can be very detailed, but for comparison purposes and transparency, the approach used here is a simplified version. This allows greater scrutiny of the underlying data and assumptions, improving transparency and the confidence in the analysis, as well as facilitating the comparison of costs by country or region for the same technologies in order to identify what are the key drivers in any differences. The three indicators that have been selected are: Equipment cost (factory gate FOB and delivered at site CIF); Total installed project cost, including fixed financing costs; and the levelized cost of electricity LCOE [12].

\subsubsection{Initial Cost}

The equipment cost means the total turbines cost which equal the cost of one turbine $\times$ number of turbines. The equipment cost $=2.1127 \times 10^{6} \$ \times 33=69.718$ M\$.

The auxiliary cost is other than those of the turbine itself, in other words foundation, grid connection, electrical installation, road construction, financial charges and so on. Which equal $5 \%$ of equipment cost $\left(0.05 \times \$ 69.718 \times 10^{6}\right)=$ 3.4859 M\$ [13].

The cost of installation is part of the cost of the asset. An asset's cost is considered to be all of the costs of getting an asset in place and ready for use. Installation cost $=10 \%$ of (equipment cost + auxiliary cost $)=0.10 \times \$(69.718+3.4859)$ $\times 10^{6}=7.3204 \mathrm{M} \$[13]$.

Initial or capital cost $=$ the equipment cost + the auxiliary cost + Installation cost $=(69.718+3.4859+7.3204) \times 10^{6}=80.5243 \mathrm{M} \$[14]$.

\subsubsection{Operating and Maintenance Cost}

Operating (Operational) costs are the expenses which are related to the operation of a business, or to the operation of a device, component, and piece of equipment or facility. They are the cost of resources used by an organization just to maintain its existence [13].

"Maintenance Expenses" the costs incurred to keep an item in good condition and/or good working order. When purchasing an item that requires upkeep, consumers should consider not just the initial price tag, but also the item's ongoing maintenance expenses $\mathrm{O} \& \mathrm{M}$ cost $=5 \%$ of initial cost $=(0.05) \times 80.5243$ $\times 10^{6}=4.026 \mathrm{M} \$[14]$.

\subsubsection{Total Life Cycle Costing (TLCC) Method of the Wind Turbine System}

Life cycle costing is a commonly used method for the economic evaluation of energy producing systems based on the principles of the "time value" of money. The LCC method summarizes expenditures and revenues occurring over time into a single parameter or number, so that an economically based choice can be made. LCC methodology takes the parameters of inflation and interest applied to money and uses a model based on the time value of money to project a "present value" for an investment at any time in the future [7]. 
The total life cycle cost $($ TLCC $)=\mathrm{O} \& \mathrm{M}$ cost + Initial cost $=(4.026+$ $80.5243) \times 10^{6}=84.5503 \mathrm{M} \$[7]$.

Figure 10 shows the Net present cost summary.

\subsubsection{Levelized Cost of Electricity (LCOE)}

The levelized cost of electricity (LCOE) is a measure of a power source which attempts to compare different methods of electricity generation on a consistent basis. It is an economic assessment of the average total cost to build and operate a power-generating asset over its lifetime divided by the total energy output of the asset over that lifetime. The LCOE can also be regarded as the average minimum cost at which electricity must be sold in order to break-even over the lifetime of the project [8].

By Homer software, the levelized cost of electricity $=0.05423 \$ / \mathrm{kWh}$.

\subsubsection{Payback Period (PbP)}

The payback period is the length of time required to recover the cost of an investment. The payback period of a given investment or project is an important determinant of whether to undertake the position or project, as longer payback periods are typically not desirable for investment positions. The payback period ignores the time value of money, unlike other methods of capital budgeting, such as net present value, internal rate of return or discounted cash flow.

$\mathrm{PbP}=$ Initial cost $(\$) /$ Energy charge $(\$ /$ year $)=\left(80.5243 \times 10^{6}\right) /(11.489278 \times$ $\left.10^{6}\right)=7$ years $[9]$.

\section{Results and Discussion}

\subsection{Sensitivity Analysis}

\subsubsection{Hub Height Sensitivity Analysis}

To fully assess how a change in a design parameter affects the myriad of objectives in system performance and cost, a holistic and integrated approach is needed. sensitivity analysis is to determine how key turbine configuration parameters affect overall system performance and cost and explore system-level

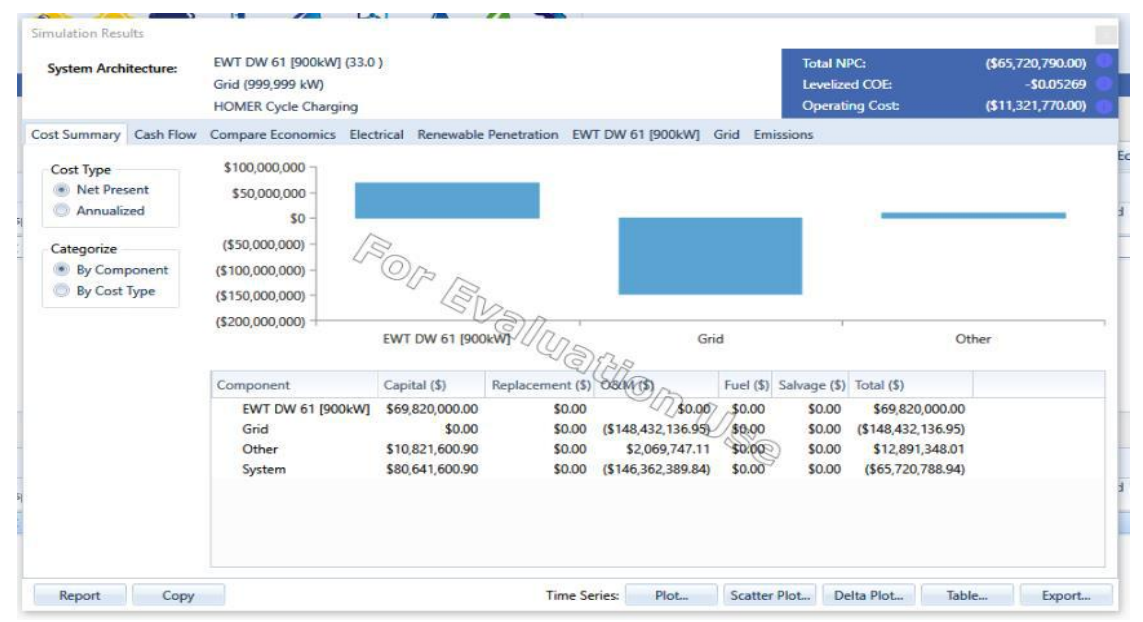

Figure 10. Cost summary from HOMER Pro. 
relationships for different configurations of the system tool using different model combinations. In this research we used HOMER Software to study the sensitivity of the hub height and rated capacity. After choosing the specific wind turbine for this project we need to make sure that it has the best proprieties for the best results. The turbine we choose EWT DW61 [900 kW] has two hub height, $75 \mathrm{~m}$ and $50 \mathrm{~m}$. Sensitivity analysis has been done to $50 \mathrm{~m}$ hub height and then we compare the following results shown in Table 6 with the $75 \mathrm{~m}$ hub height.

This variation effects the monthly power output, the energy sold to the grid and therefore effects the energy charge and the payback period. Figure 11 and Figure 12 shows the grid sales and the monthly power output for the $50 \mathrm{~m}$ hub height. The annually energy charge for this turbine is $10,655,154.46 \$$ and it's less than the previous height by $834,123.54 \$$ and the total energy sold to the grid equal $89,539,113 \$$ which is less than the $75 \mathrm{~m}$ hub height turbine by $7,009,446 \$$, which effect the payback period. From these results we notice that the most efficient height is $75 \mathrm{~m}$ hub height.

\begin{tabular}{|c|c|c|c|c|c|c|c|}
\hline \multirow[t]{2}{*}{ jle Penetration } & \multicolumn{2}{|l|}{ VT D } & \multicolumn{2}{|c|}{ Emissions } & & \multirow[b]{2}{*}{$\psi$} & \multirow[b]{3}{*}{$\begin{array}{l}\text { Deariand } \\
\text { Charge (\$) }\end{array}$} \\
\hline & \multicolumn{3}{|c|}{ Rate Schedule: } & \multicolumn{2}{|l|}{ All } & & \\
\hline Month & $\begin{array}{l}\text { Enerqy } \\
\text { Purchased } \\
\text { (kWh) }\end{array}$ & $\begin{array}{l}\text { Frnay } \\
\text { Sold (kWh) }\end{array}$ & $\begin{array}{l}\text { Net Er } \\
\text { Purcha } \\
\text { (kWhi) }\end{array}$ & $\begin{array}{l}\text { nergy } \\
\text { ased }\end{array}$ & $\begin{array}{l}\text { Peak } \\
\text { Demand } \\
(\mathrm{kW})\end{array}$ & Energy Charge (\$) & \\
\hline Ranuary & 0 & $10,217,847$ & $-10,2$ & 17,84 & 0 & $(\$ 1,215,923,83)$ & so \\
\hline Fobruary & 0 & $10,074,689$ & $-10,07$ & 74,68 & 0 & (\$1,198,887.98) & 30 \\
\hline March & 0 & $9,693,762$ & $-9,693$ & 3,762 & 0 & $(\$ 1,153,557,73)$ & 50 \\
\hline Apral & 0 & $5,659,938$ & $-5,65$ & 9,938 & 0 & (56/3.532.68) & so \\
\hline May & 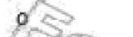 & $7,602,713$ & $-7,602$ & 2,713 & 0 & $(5914,24 \geq 85)$ & so \\
\hline kune & 0 & 6.704 .600 & -6.70 & 4.600 & 0 & $(\$ 797.947 .44)$ & $\$ 0$ \\
\hline Nuly & 0 & $7,035,981$ & $.7,085$ & 5,287 & 0 & $(\$ 950,248.47)$ & so \\
\hline Augest & 0 & $8,611,460$ & -8.61 & 1.460 & 0 & $(\$ 1.024 .763 .73)$ & 50 \\
\hline September & 0 & $4,924,929$ & 492 & 4,929 & 0 & $(\$ 586,066.57)$ & 30 \\
\hline Ortober & 0 & $4,267_{n} 144$ & $-4,26$ & 7,744 & 0. & (\$507, $700-13)$ & $\$ 0$ \\
\hline Nowamber & 0 & $5,166,925$ & $-5,166$ & 5925 & 0 & (\$614.864.08) & $\$ 0$ \\
\hline December & 0 & $8,549,823$ & $-8,54$ & 9.823 & 5 & (\$1,0T/,428.981) & SEI \\
\hline Annual & (1) & $89,539,113$ & $-89,5$ & 39,11 & 0 & $(\$ 10,655,154.46)$ & 30 \\
\hline
\end{tabular}

Figure 11. Grid sales and energy charge for EWT DW61 [900 KW], 50m hub height.

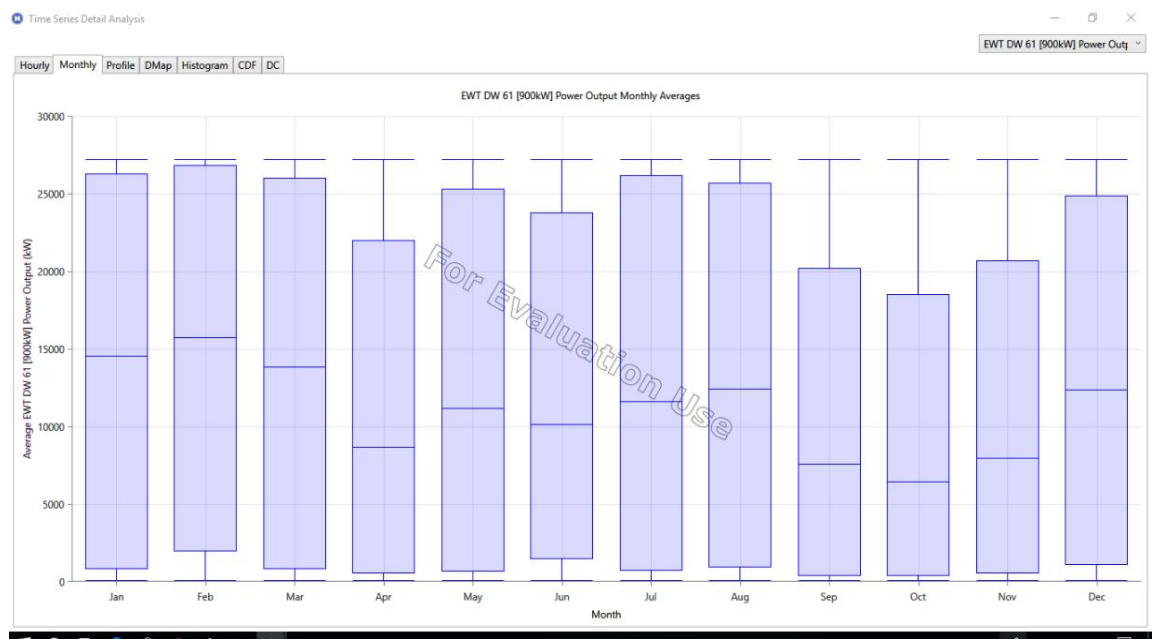

Figure 12. Monthly power output kW. 
Table 6. Sensitivity results for $50 \mathrm{~m}, 75 \mathrm{~m}$ hub height.

\begin{tabular}{cccccccc}
\hline $\begin{array}{c}\text { Hub } \\
\text { height } \\
(\mathrm{m})\end{array}$ & $\begin{array}{c}\text { Capacity } \\
\text { Factor } \\
(\%)\end{array}$ & $\begin{array}{c}\text { Total } \\
\text { production } \\
(\mathrm{kWh})\end{array}$ & $\begin{array}{c}\text { Operation } \\
\text { hours }(\mathrm{hr})\end{array}$ & $\begin{array}{c}\text { Levelized } \\
\text { cost }(\$ / \mathrm{kWh})\end{array}$ & $\begin{array}{c}\text { Capital } \\
\text { cost }(\$)\end{array}$ & $\begin{array}{c}\text { O \& M } \\
(\$)\end{array}$ & $\begin{array}{c}\text { NBC } \\
(\$)\end{array}$ \\
\hline 50 & 34.4 & $89,539,113$ & 8240 & 0.06 & $80,524,300$ & $2,081,899$ & $55,138,490$ \\
70 & 37.1 & $96,548,559$ & 8286 & 0.055 & $80,524,300$ & $4.026^{\star} 10^{\wedge} 6$ & $65,998,590$ \\
\hline
\end{tabular}

\subsubsection{Power Capacity Sensitivity Analysis}

Different power turbines with different power capacity have been analyzed. Table 7 shows the results for sensitivity analysis. From Table 7 we notice that the most suitable turbine for the wind speed data in the selected site is EWT DW61 [900 kW]. Which give a prove that our choice for this turbine is appropriate it has the highest capacity factor and its hours of operation are very high, it works most of the year [15].

\subsection{Environmental Impact}

\section{Emissions}

Recent data and analysis have made it clear that the emissions savings from adding wind energy to the grid are even larger than had been commonly thought. In addition to each kWh of wind energy directly offsetting a kWh that would have been produced by a fossil-fired power plant, new analyses show that wind plants further reduce emissions by forcing the most polluting and inflexible power plants offline and causing them to be replaced by more efficient and flexible types of generation [15].

Electricity from wind turbines replaces the output of coal-fired power stations. British Wind Energy Association (BWEA) calculations use typical emissions from coal-fired plant of:

$860 \mathrm{~g} \mathrm{CO}_{2} / \mathrm{kWh}, 10 \mathrm{~g} \mathrm{SO}_{2} / \mathrm{kWh}$ and $3 \mathrm{~g} \mathrm{NO}_{\mathrm{x}} / \mathrm{kWh}$.

According to [16], emissions reductions by using wind energy instead of coal-fired plant are:

$$
\begin{aligned}
& \mathrm{CO}_{2}(\text { tons })=(\mathrm{A} \times 0.3 \times 8760 \times 860) / 1000 . \\
& \mathrm{SO}_{2}(\text { tons })=(\mathrm{A} \times 0.3 \times 8760 \times 10) / 1000 . \\
& \mathrm{NO}_{\mathrm{x}}(\text { tons })=(\mathrm{A} \times 0.3 \times 8760 \times 3) / 1000 .
\end{aligned}
$$

Where, A: the rated capacity of the wind energy development in MW; 0.3: Capacity factor of the wind turbine and 8760: is the number of hours in a year.

$$
\begin{aligned}
& \mathrm{CO}_{2}(\text { tons })=(29.7 \mathrm{MW} \times 0.3 \times 8760 \times 860) / 1000=67124.4 \text { tons. } \\
& \mathrm{SO}_{2}(\text { tons })=(29.7 \mathrm{MW} \times 0.3 \times 8760 \times 10) / 1000=780.52 \text { tons. } \\
& \mathrm{NO}_{\mathrm{x}}(\text { tons })=(29.7 \mathrm{MW} \times 0.3 \times 8760 \times 3) / 1000=234.2 \text { tons. }
\end{aligned}
$$

[17] reported the emissions rates of the thermal power plant (fuel oil) are $68.46 \mathrm{~g} / \mathrm{kWh}$ for carbon, $2.047 \mathrm{~g} / \mathrm{kWh}$ for Sulphur and $0.815 \mathrm{~g} / \mathrm{kWh}$ for Nitrogen, and the emissions reduction using wind power instead of fuel oil power plant is:

$$
\begin{aligned}
& \mathrm{CO}_{2}(\text { ton })=(\mathrm{A} \times 0.3 \times 8760 \times 68.46) / 1000 . \\
& \mathrm{SO}_{2}(\text { ton })=(\mathrm{A} \times 0.3 \times 8760 \times 2.047) / 1000 .
\end{aligned}
$$


Table 7. Sensitivity cases by power capacity.

\begin{tabular}{ccccccc}
\hline Turbine type & $\begin{array}{c}\text { Power } \\
(\mathrm{kW})\end{array}$ & $\begin{array}{c}\text { Capacity } \\
\text { factor }(\%)\end{array}$ & $\begin{array}{c}\text { No. of } \\
\text { turbines }\end{array}$ & $\begin{array}{c}\text { Total } \\
\text { production } \\
(\mathbf{k W h})\end{array}$ & $\begin{array}{c}\text { Total } \\
\text { NBC } \\
\mathbf{( \$ )}\end{array}$ & $\begin{array}{c}\text { Levelized } \\
\text { cost } \\
(\$ / \mathbf{k W h})\end{array}$ \\
\hline Vestas V47 & 660 & 29.2 & 51 & $86,183,833$ & $29,144,135$ & 0.040 \\
Enercon E53 & 800 & 35.6 & 38 & $94,917,855$ & $63,831,000$ & 0.056 \\
EWT DW61 & 900 & 37.1 & 33 & $96,548,559$ & $65,998,590$ & 0.055 \\
Vestas V82 & 1650 & 33.8 & 22 & $107,558,673$ & $46,387,238$ & 0.050 \\
\hline
\end{tabular}

$\mathrm{NO}_{\mathrm{x}}($ ton $)=(\mathrm{A} \times 0.3 \times 8760 \times 0.815) / 1000$.

$\mathrm{CO}_{2}($ ton $)=5343.4, \mathrm{SO}_{2}($ ton $)=159.8, \mathrm{NO}_{\mathrm{x}}($ ton $)=63.6[13]$.

In a study conducted by the Institute of Point Carbon International, based in Oslo, that the price of carbon reduction will increase in international stock exchanges to reach the price of tons in 2010 to 37 dollars per ton, while in 2020 will reach 54 dollars per ton.

When using wind energy instead of coal-fired plant, the cost by reduction.

$\mathrm{CO}_{2}=\$ 54 \times 67124.4=3.625 \mathrm{M} \$$.

While by using wind power instead of fuel oil power plant, the cost by reduction.

$\mathrm{CO}_{2}=\$ 54 \times 5343.4=2.89 \times 10^{\wedge} 5 \$$.

\section{Conclusions}

This study demonstrated the allowable capacity in Bab Al-Hawa site, which is 29.7 MW with 33 wind turbines of $900 \mathrm{~kW}$ power capacity. Grid connecting simulation was done by HOMER Software and the results for operating through a one year were obtained with a 96,548,559 kWh electricity generated in one year. Levelized cost of electricity was obtained as $0.055 \$ / \mathrm{kWh}$, considering a 0.119 $\$ / \mathrm{kWh}$ grid sellback price, a saving of about $11,489,278 \$$ every year.

It also demonstrated the capabilities and limitations of a new modeling tool of integrated wind plant system, by using HOMAR software tool to create three different model configurations and analyzing each of them using a global sensitivity analysis of key turbine configuration parameters on wind plant system performance and overall COE. The results of the COE to turbine configuration parameters of rated power, hub height were obtained and discussed and it proved that the chosen turbine capacity was the most suitable for the site and the highest hub height was the best.

\section{Conflicts of Interest}

The authors declare no conflicts of interest regarding the publication of this paper.

\section{References}

[1] Ali, K. (2011) Design of Smart Power Grid Renewable Energy Systems. John Wiley and Sons, Inc., Hoboken, New Jersey. 
[2] Khambalkar, V.P., Gadge, S.R., Dahatonde, S.B., Kale, M.U. and Karale, D.S. (2007) Wind Energy Cost and Feasibility of a 2 MW Wind Power Project. International Energy Journal, 8, 285-290. http://www.serd.ait.ac.th/reric

[3] Badran, O.O. (2000) Wind Energy Research and Development in Jordan. World Renewable Energy Congress VI, Brighton, UK, 1-7 July 2000, Part VI, 2360-2363. https://doi.org/10.1016/B978-008043865-8/50512-2

[4] Hossain, M.S., Raha, B.K., Paul, D. and Haque, M.E. (2015) Optimization and Generation of Electrical Energy Using wind Flow in Rural Area of Bangladesh. Research Journal of Applied Sciences, Engineering and Technology, 10, 895-902. https://doi.org/10.19026/rjaset.10.2445

[5] Al-Nhoud, O. and Al-Smairan, M. (2015) Assessment of Wind Energy Potential as a Power Generation Source in the Azraq South, Northeast Badia, Jordan. Modern Mechanical Engineering, 5, 87-96. https://doi.org/10.4236/mme.2015.53008

[6] Sabra, Z. (1999) Winds Energy in Jordan-Use and Perspectives. DEWI Magazine, No. 15.

[7] Wind power (2017) https://en.wikipedia.org/wiki/Wind_power

[8] (2017) Sketchup: 3D Modeling for Everyone. http://www.sketchup.com/

[9] (2017) Reliability Growth and Repairable System Analysis. http://reliawiki.org/index.php/Main_Page

[10] National Renewable Energy Laboratory (2017) The HOMER Pro ${ }^{\circledast}$ Microgrid Software by HOMER Energy. https://www.homerenergy.com/products/pro/index.html

[11] Aihara, A., Uzunoğlu, B. and Goude, A. (2016) Wind Flow Resource Analysis of Urban Structures, a Validation Study. 12 th EAWE PhD Seminar on Wind Energy in Europe, DTU Lyngby, Denmark, 25-27 May 2016, Poster Session.

[12] IRENA (2012) Renewable Energy Technologies: Cost Analysis Series. https://www.irena.org/documentdownloads/publications/re_technologies_cost_anal ysis-wind_power.pdf

[13] Al-Smairan, M. (2006) Investigation of a Hybrid Wind-Photovoltaic Electrical Energy System for a Remote Community. Ph.D. Dissertation, Coventry University, Coventry, UK.

[14] Manwell, J.F., McGowan, J.G. and Rogers, A.L. (2002) Wind Energy Explained, Theory, Design and Application. John Wiley \& Sons Ltd., Baffins Lane, Chichester, West Sussex PO19 1UD, England.

[15] Dykes, K., Ning, A., King, R., Graf, P., Scott, G. and Veers, P. (2014) Sensitivity Analysis of Wind Plant Performance to Key Turbine Design Parameters: A Systems Engineering Approach Preprint. 32nd ASME Wind Energy Symposium, AIAA SciTech Forum, National Harbor, Maryland, 13-17 January 2014. https://doi.org/10.2514/6.2014-1087

[16] BWEA (2002) Promoting Winds Energy in and around the UK. http://www.britishwindenergy.co.uk

[17] Chedid, R., Akiki, H. and Saifur, R. (1997) A Decision Support Technique for the Design of Hybrid Solar-Wind Power Systems. IEEE Transactions on Energy Conversion, 13, 76-83. https://doi.org/10.1109/60.658207 


\section{Appendix 1}

Table A1. Average daily wind speed for year 2012 in Bab Al-Hawa/Irbid (Using HOMER).

\begin{tabular}{|c|c|c|c|c|c|c|}
\hline Day /Month & January & February & March & April & May & June \\
\hline Day 1 & 7.92109 & 8.90132 & 7.58504 & 5.07893 & 6.40071 & 6.1284 \\
\hline Day 2 & 7.5749 & 8.42122 & 7.29367 & 5.590792 & 6.42772 & 6.16455 \\
\hline Day 3 & 7.6771 & 8.45265 & 7.26376 & 5.963745 & 6.26817 & 6.30306 \\
\hline Day 4 & 8.3281 & 8.27294 & 6.8913 & 5.40457 & 6.78277 & 5.59461 \\
\hline Day 5 & 7.8032 & 8.08558 & 7.01888 & 5.316189 & 6.59595 & 5.46394 \\
\hline Day 6 & 7.32653 & 8.72426 & 7.45731 & 5.807444 & 6.39956 & 6.01874 \\
\hline Day 7 & 7.477343 & 8.47784 & 7.46001 & 5.705775 & 6.18228 & 5.83263 \\
\hline Day 8 & 7.349274 & 7.96946 & 7.79978 & 5.393412 & 6.21772 & 6.24071 \\
\hline Day 9 & 7.684189 & 7.44174 & 7.94098 & 5.432679 & 6.40937 & 6.09516 \\
\hline Day 10 & 7.67443 & 8.74238 & 6.6416 & 5.699964 & 6.82527 & 6.27102 \\
\hline Day 11 & 7.577038 & 7.98685 & 7.31989 & 5.872741 & 6.61776 & 5.50654 \\
\hline Day 12 & 7.711171 & 7.88769 & 7.47765 & 5.265135 & 6.65512 & 6.51665 \\
\hline Day 13 & 7.805261 & 7.95287 & 6.85336 & 5.714893 & 6.59802 & 6.12389 \\
\hline Day 14 & 8.360634 & 7.92804 & 7.98713 & 5.74259 & 6.2901 & 6.05773 \\
\hline Day 15 & 7.913335 & 8.17421 & 7.52876 & 5.778131 & 6.73612 & 5.70625 \\
\hline Day 16 & 7.226863 & 8.36067 & 6.90181 & 5.405892 & 6.1047 & 5.85207 \\
\hline Day 17 & 7.636744 & 8.76615 & 7.24847 & 5.279893 & 5.72775 & 6.1285 \\
\hline Day 18 & 7.02517 & 7.84736 & 7.52681 & 5.26044 & 6.01864 & 5.7632 \\
\hline Day 19 & 7.471485 & 8.8406 & 7.822 & 5.343384 & 6.30413 & 6.09896 \\
\hline Day 20 & 8.066749 & 8.79018 & 7.71757 & 5.194877 & 6.38176 & 5.78773 \\
\hline Day 21 & 7.705655 & 8.02971 & 7.0681 & 5.036641 & 6.54478 & 5.83308 \\
\hline Day 22 & 7.896198 & 8.42358 & 7.3359 & 5.488821 & 6.85704 & 5.78794 \\
\hline Day 23 & 7.951189 & 8.59281 & 6.80683 & 5.447655 & 6.56753 & 6.16862 \\
\hline Day 24 & 7.135522 & 8.47313 & 7.60487 & 5.84153 & 6.49028 & 5.45083 \\
\hline Day 25 & 7.531938 & 8.35693 & 7.627 & 5.892185 & 5.96572 & 6.15403 \\
\hline Day 26 & 7.792741 & 8.05491 & 7.71939 & 5.571628 & 6.00902 & 6.41664 \\
\hline Day 27 & 7.108774 & 7.50724 & 7.47987 & 5.656962 & 6.08739 & 6.30507 \\
\hline Day 28 & 6.929588 & 7.785859 & 7.70807 & 5.463958 & 5.0148 & 6.14665 \\
\hline Day 29 & 8.24849 & - & 7.1686 & 5.398952 & 6.09608 & 5.9026 \\
\hline Day 30 & 7.452032 & - & 7.20908 & 5.423935 & 5.64134 & 6.07235 \\
\hline Day 31 & 8.242718 & - & 6.93976 & - & 6.2361 & - \\
\hline
\end{tabular}


M. Al-Smairan, O. Al-Nhoud

\begin{tabular}{|c|c|c|c|c|c|c|}
\hline Day/Month & July & August & September & October & November & December \\
\hline Day 1 & 6.87407 & 6.916591 & 5.51036 & 4.691 & 5.26543 & 6.4972 \\
\hline Day 2 & 6065977 & 6.45113 & 5.01902 & 4.8781 & 5.20577 & 6.00948 \\
\hline Day 3 & 6.31305 & 6.582939 & 4.92377 & 4.80555 & 5.62839 & 6.55553 \\
\hline Day 4 & 6.62634 & 5.51855 & 5.25804 & 4.78086 & 5.36357 & 6.46985 \\
\hline Day 5 & 6.24013 & 6.554474 & 4.89536 & 4.87327 & 5.35173 & 6.66043 \\
\hline Day 6 & 6.47759 & 6.810235 & 5.07993 & 3.9865 & 5.32009 & 6.77038 \\
\hline Day 7 & 6.63625 & 6.785424 & 5.02024 & 4.41764 & 5.30442 & 6.44784 \\
\hline Day 8 & 5.9712 & 6.746577 & 4.69764 & 4.83343 & 5.16815 & 6.87939 \\
\hline Day 9 & 6.54106 & 6.631097 & 5.01091 & 4.60428 & 5.28755 & 6.72463 \\
\hline Day 10 & 7.12692 & 7.22796 & 5.45887 & 4.74342 & 5.38438 & 7.05488 \\
\hline Day 11 & 6.1263 & 6.618827 & 5.32716 & 4.961 & 5.55513 & 7.11338 \\
\hline Day 12 & 6.40836 & 7.054651 & 4.74004 & 4.62146 & 5.02865 & 6.84411 \\
\hline Day 13 & 6.51762 & 6.669315 & 5.03163 & 4.87369 & 5.21919 & 6.70829 \\
\hline Day 14 & 6.57138 & 6.859497 & 4.88975 & 4.82877 & 4.56433 & 6.66856 \\
\hline Day 15 & 6.74754 & 6.592865 & 5.112 & 4.75864 & 5.26062 & 6.77531 \\
\hline Day 16 & 6.63239 & 6.886163 & 5.59289 & 4.73151 & 5.47544 & 7.07269 \\
\hline Day 17 & 6.35107 & 6.84243 & 5.28518 & 4.99302 & 5.55564 & 7.15485 \\
\hline Day 18 & 6.8244 & 6.118289 & 4.80029 & 5.02469 & 5.13114 & 7.21368 \\
\hline Day 19 & 6.64931 & 7.01842 & 5.42438 & 4.91329 & 5.06901 & 6.92258 \\
\hline Day 20 & 6.13701 & 6.977888 & 5.11083 & 4.38823 & 4.86484 & 6.94437 \\
\hline Day 21 & 6.23861 & 6.955362 & 5.09567 & 4.52189 & 5.39654 & 6.40904 \\
\hline Day 22 & 6.9435 & 7.132056 & 5.49693 & 5.12119 & 5.05044 & 7.36235 \\
\hline Day 23 & 6.53918 & 6.976986 & 5.3537 & 4.85869 & 5.32728 & 6.80295 \\
\hline Day 24 & 6.63392 & 6.772573 & 5.63614 & 4.81676 & 5.32457 & 6.6382 \\
\hline Day 25 & 6.40087 & 6.328518 & 5.05556 & 4.90086 & 5.13838 & 5.97577 \\
\hline Day 26 & 6.21397 & 6.931188 & 5.43472 & 4.99952 & 5.24614 & 6.61731 \\
\hline Day 27 & 5.68306 & 6.735539 & 5.38135 & 4.68692 & 5.31347 & 6.81464 \\
\hline Day 28 & 6.34339 & 6.373096 & 5.30764 & 4.98745 & 5.6159 & 7.02238 \\
\hline Day 29 & 6.5092 & 6.725745 & 5.14627 & 4.82009 & 5.46403 & 7.31815 \\
\hline Day 30 & 6.61368 & 7.401535 & 4.95394 & 4.95572 & 5.35082 & 6.47118 \\
\hline Day 31 & 6.64449 & 7.441115 & - & 5.25347 & - & 6.77221 \\
\hline
\end{tabular}




\section{Appendix 2}

Table A2. Wind speed frequency and occurrences.

\begin{tabular}{|c|c|c|c|}
\hline Lower wind speed $(\mathrm{m} / \mathrm{s})$ & Upper wind speed $(\mathrm{m} / \mathrm{s})$ & Frequency (\%) & Occurrences \\
\hline 0.0 & 0.5 & 0.00 & 0.0 \\
\hline 0.5 & 1 & 0.0 & 0.0 \\
\hline 1 & 1.5 & 0.0 & 0.0 \\
\hline 1.5 & 2 & 0.0228 & 2 \\
\hline 2 & 2.5 & 0.1484 & 13 \\
\hline 2.5 & 3 & 0.4566 & 40 \\
\hline 3 & 3.5 & 1.1872 & 104 \\
\hline 3.5 & 4 & 2.6826 & 235 \\
\hline 4 & 4.5 & 5.2283 & 458 \\
\hline 4.5 & 5 & 8.5160 & 746 \\
\hline 5 & 5.5 & 11.5753 & 1014 \\
\hline 5.5 & 6 & 13.0479 & 1143 \\
\hline 6 & 6.5 & 12.6712 & 1110 \\
\hline 6.5 & 7 & 11.8607 & 1039 \\
\hline 7 & 7.5 & 10.0457 & 880 \\
\hline 7.5 & 8 & 8.2420 & 722 \\
\hline 8 & 8.5 & 5.8333 & 511 \\
\hline 8.5 & 9 & 3.9269 & 344 \\
\hline 9 & 9.5 & 2.3516 & 206 \\
\hline 9.5 & 10 & 1.3356 & 117 \\
\hline 10 & 10.5 & 0.5594 & 49 \\
\hline 10.5 & 11 & 0.2283 & 20 \\
\hline 11 & 11.5 & 0.0685 & 6 \\
\hline 11.5 & 12 & 0.0 & 0.0 \\
\hline 12 & 12.5 & 0.0114 & 1 \\
\hline 12.5 & 13 & 0.0 & 0 \\
\hline
\end{tabular}

